\title{
Kişisel Dozimetre Taşıyan Çalışanlarda Aşırı İş Yükünün Örgütsel Bağlılık ve İş Tatmini Üzerindeki Etkisi \\ (The Effect of Work Overload on Organizational Commitment and Job Satisfaction of Employees Carrying Personal Dosimeters)
}

\section{Fatma MANSUR iD a Firat SEYHAN iD $_{b}$}

a Ankara Hacı Bayram Veli Üniversitesi, İktisadi ve İdari Bilimler Fakültesi, Ankara, Türkiye. fatma.mansur@hbv.edu.tr

b Sağlık Bilimleri Üniversitesi, Yönetim ve Organizasyon Bölümü, Ankara, Türkiye. firat.seyhan@sbu.edu.tr

\begin{tabular}{|c|c|}
\hline MAKALE BİLGİSİ & ÖZET \\
\hline $\begin{array}{l}\text { Anahtar Kelimeler: } \\
\text { Sağlık Kurumları }\end{array}$ & $\begin{array}{l}\text { Amaç - Bu çalışmanın amacı, sağlık kurumlarında iyonize radyasyon alanında görev yapıp kişisel dozimetre } \\
\text { taşıyan çalışanlarda aşırı iş yükünün örgütsel bağlllık ve iş tatmini üzerindeki etkisi belirlemektir. }\end{array}$ \\
\hline $\begin{array}{l}\text { Dozimetre } \\
\text { Aşırı İş Yükü } \\
\text { Örgütsel Bağlllık } \\
\text { İş Tatmini }\end{array}$ & $\begin{array}{l}\text { Yöntem - Çalışmanın evrenini Ankara ilinde faaliyet gösteren kamu ve özel sağlık kuruluşlarında görevli } \\
\text { kişisel dozimetre taşıyan çalışanlar oluşturmaktadır. Araştırma verilerini elde etmek amacıyla online anket } \\
\text { uygulanmış ve } 191 \text { katılımc araştırmanın örneklemini oluşturmuştur. Veriler için değişkenlerin miktarını ve } \\
\text { türünü belirlemek amacıyla tekil tarama modeli, değişkenler arasındaki ilişkinin varlığını ve değişimin } \\
\text { yönünü belirlemek amacıyla da ilişkisel tarama modeli kullanılmıştır. Elde edilen veriler istatistiksel analiz } \\
\text { programı ile analiz edilmiş ve yorumlanmıştır. }\end{array}$ \\
\hline $\begin{array}{l}2021 \\
\text { Revizyon Tarihi } 5 \text { Mayıs } \\
2021 \\
\text { Kabul Tarihi } 1 \text { Haziran } \\
2021\end{array}$ & $\begin{array}{l}\text { Bulgular - Araştırma sonucunda aşırı iş yükü ile iş tatmini arasında ters yönde ve çok zayıf ilişkinin } \\
\text { bulunduğu görülmüştür. İş tatmini ile duygusal ve normatif bağlllık arasında pozitif yönde ve orta düzeyde, } \\
\text { devamlılık bağlllığı ile ise çok zayıf bir ilişki görülmüştür. Duygusal, devamlılık ve normatif bağlllık } \\
\text { boyutlarından oluşan örgütsel bağlllık ile aşırı iş yükü arasında istatistiksel olarak anlamlı bir ilişki bulunmaz } \\
\text { iken, iş tatmini arasında pozitif yönde ve orta düzeyde ilişki bulunmuştur. }\end{array}$ \\
\hline $\begin{array}{l}\text { Makale Kategorisi: } \\
\text { Araştırma Makalesi }\end{array}$ & $\begin{array}{l}\text { Tartışma - Araştırma bulgularından özellikle iş tatmini ve örgütsel bağlılık arasında pozitif ve orta düzeydeki } \\
\text { ilişki; aşırı iş yükü ve iş tatmini arasındaki negatif ve zayıf ilişki literatürdeki çalışmalar ile desteklenmektedir. } \\
\text { Girdisi ve çktısı insan olan sağlık kurumlarında aşırı iş yükünü dengeleyecek, radyasyona maruz kalmayı } \\
\text { en aza indirecek ya da ortadan kaldıracak ve bunun sonucu olarak da dozimetre taşıyan personelin verimlilik } \\
\text { seviyelerini, iş yaşam kalitelerini, iş tatminlerini ve örgütsel bağlılıklarını arttırıcı bir atmosfer } \\
\text { oluşturulabilmesi yönündeki tüm çabalar desteklenmeli ve tüm yasal önlemler alınmalıdır. }\end{array}$ \\
\hline
\end{tabular}

ARTICLE INFO ABSTRACT

Keywords:

Health Institutions

Dosimeter

Overwork

Organizational

Commitment

Job Satisfaction

Received 9 March 2021

Revised 5 May 2021

Accepted 1 June 2021

Article Classification: Research Article

\begin{abstract}
Purpose - The aim of this study is to determine the effect of excessive workload on organizational commitment and job satisfaction among employees who work in the field of ionizing radiation in healthcare institutions and carry personal dosimeters.
\end{abstract}

Design/methodology/approach - The population of the study consists of employees carrying personal dosimeters working in public and private health institutions operating in Ankara. An online questionnaire was applied to obtain research data and 191 participants formed the sample of the study. The singular survey model was used to determine the amount and type of variables for the data, and the relational survey model was used to determine the existence of the relationship between variables and the direction of change. The data obtained were analyzed and interpreted with a statistical analysis program.

Findings - As a result of the research, it has been observed that there is an inverse and very weak relationship between overwork and job satisfaction. There was a positive and moderate relationship between job satisfaction and emotional and normative commitment, and a very weak relationship with continuity commitment. While there is no statistically significant relationship between organizational commitment, which consists of emotional, continuity and normative commitment dimensions, and excessive workload, a positive and moderate relationship was found between job satisfaction.

Discussion - Among the findings of the research, positive and moderate relationship between job satisfaction and organizational commitment; the negative and weak relationship between overwork and job satisfaction is supported by studies in the literature. All efforts should be supported to create an atmosphere that will balance excessive workload, minimize or eliminate radiation exposure, and consequently increase the productivity levels, work life quality, job satisfaction and organizational commitment of the personnel carrying dosimeters in healthcare institutions whose input and output are human and all legal measures must be taken.

\section{Önerilen Atıf/ Suggested Citation}

Mansur, F., Seyhan, F. (2021). Kişisel Dozimetre Taşıyan Çalışanlarda Aşırı İş Yükünün Örgütsel Bağlllık ve İş Tatmini Üzerindeki Etkisi, İşletme Araştırmaları Dergisi, 13 (2), 1033-1049. 


\section{Giriş}

Bireylerin mevcut sağlık durumu ile yapmış olduğu iş arasında kuvvetli ve yakın bir ilişki bulunmakta olup, aynı şekilde çalışmanın da bireylerin hem fiziksel hem de ruhsal yönden gelişmesine katkı sağlarken onları daha sağlıklı bir konuma getirdiği bilinmektedir. Ancak çalışma ortamında bulunan olumsuz unsurlar sözü edilen bu durumu tersine çevirmekte, çalışanların örgüte olan bağlılığını azalttığı gibi iş tatmin düzeyinde de negatif yönlü etkiye sebep olmaktadır (Karaca, 2001; Eren, 2006; Graham vd., 2000; Adams ve Bond, 2000). Bahse konu çalışanların, sağlık kurumlarındaki en yoğun birimlerden biri olan radyoloji bölümünde iyonize radyasyon alanında görev yapan çalışanlar olduğu düşünüldügünde, bu negatif etkinin, aşırı iş yükünün ve iyozine radyasyonun sağlı̆̆a olan olumsuz etkilerinden kaynaklı olarak, daha da arttığ göz önünde bulundurulması gereken önemli bir husustur. Çalışma ortamında sürekli maruz kalınan iyonize radyasyon gibi faktörler, kısa ya da uzun dönemde bireyin hem fiziksel hem de ruhsal sağlığını negatif yönde etkilemenin yanı sıra kişinin işten ayrılma niyetine etki edebilmektedir (Helvacı, 2011; Saygın vd., 2011; Balsak, 2014).

Radyasyonun tanı ve tedavide kullanımının sağlık sektöründe devrim niteliğinde bir yenilik olduğunun bilinmesinin yanı sıra, iyonize radyasyonun sağlığa olan olumsuz etkileri bilimsel olarak kanıtlanmış ve radyasyondan korunmanın önemini arttırmıştır (Hammer vd., 2013; Blakely vd., 2011; Şaşkın,2010). İyonlaştırıcı radyasyon yayan cihaz ya da radyoaktif kaynaktan yayılan radyasyonun düzeyinin bilinmesi ve buna göre ihtiyaç durumunda gerekli önlemlerin alınması son derece önemlidir. Bu bağlamda radyasyon alanında çalışan personelin maruz kaldığı toplam vücut dozunun rutin olarak ölçülmesi amacıyla dozimetreler kullanılmakta olup ülkemizde dozimetrelerin ve dozların kontrolü Türkiye Atom Enerjisi Kurumu tarafından gerçekleştirilmektedir. Böylelikle iyonize radyasyon alanında görev yapan çalışanların maruz kalabileceği azami doz sınırları belirlenerek ve maruz kaldıkları radyasyon oranı da kişisel dozimetreler ile ölçülerek fazla doza maruz kalmalarının önüne geçilmektedir. Kişisel dozimetreler, radyasyon alanında görev yapanlar için maruz kalınan doz miktarlarının yasal sınırların altında tutulmasını sağlamak amacıyla iyonize radyasyona maruz kalma kontrolünü mümkün kılmaktadır (Alpay ve Gürdal, 2019).Sağlık kurum ve kuruluşlarında en yoğun birimlerden biri de görüntüleme merkezleridir. Bu alanda çalışanların radyasyona maruz kalma durumları her ne kadar kontrol altında ise de çalışanlar aşırı iş yükü ile karşı karşıyadır.

Aşırı iş yükü, çalışanın iş tatminsizliğinin yanı sıra yaşam tatminsizliği ile de sonuçlanan sağlık sorunlarına, örgütün tüm faaliyetleri göz önüne alındığında ise performansın azalmasına, performansın azalmasından dolayı kârın düşmesine, çalışanlarda sağlığın bozulmasına, tükenmeye ve işten ayrılma niyetinin ortaya çıkmasına neden olmaktadır (Okan ve Özbek, 2016).

$\mathrm{Bu}$ araştırmada iyonize radyasyon alanında görev yapıp kişisel dozimetre taşıyan çalışanlarda aşırı iş yükünün örgütsel bağlllık ve iş tatmini üzerindeki etkisi belirlenmeye çalışılmıştır.

\section{Kavramsal Çerçeve}

\section{1. İş Yükü Kavramı}

İş yükü, bireyin belli bir çalışma süresi içerisinde bir kazanım elde etmek amacıyla yerine getirdiği görevler olarak tanımlanmakta olup; bireyin görev sayısı, zorluk derecesi ve karmaşıklık oranının artmasının, aşırı iş yüküne neden olduğu bilinmektedir.(Çakıcı, Özkan \& Akyüz, 2013). İş yükü, organizasyon açısından bakıldığında performans ve verimlilik, çalışan açısından bakıldığında ise verilmiş olan görevin gerekliliklerini yerine getirmek için kullanılan zaman ve sarf edilen enerjiyi ifade etmektedir (Ardıç \& Polatcı, 2009).

Aşırı iş yükü ise, çalışanların örgüt içerisindeki yerine getirdiği görevlerin fazla olması, sınırlarını zorlayıcı, fiziki ve ruhsal yönden yıpratıcı görevlerin gerçekleştirilmesi olarak ifade edilmektedir (Greenhaus, Parasuraman, Granrose, Rabinowitz \& Beutell, 1989). Aşırı iş yükü hem çalışan açısından hem de örgüt açısından oldukça önemlidir. Çalışanlar, belirlenmiş olan süre içerisinde çok fazla sorumluluğunun ya da görevinin bulunduğu düşüncesine kapıldığında aşırı iş yükü, bir stres unsuru haline gelmektedir (Nasurdin ve O'driscoll, 2011:38). Çalışanlar aşırı iş yükünden kaynaklı olarak tükenmişlik, iş tatminsizliği, örgütsel stres ve gerginlik yaşarken; örgüt de mevcut çalışanların azalan performansı nedeniyle verimlilik kaybı yaşamaktadır (Gümüştekin \& Öztemiz, 2005). Aşırı iş yükü nitelik ve nicelik açısından değerlendirilmektedir. Nitelik açısından değerlendirildiğinde aşırı iş yükü, işin gerekliliklerinin çalışanların sahip olduğu 
yeteneklerinden daha fazla olmasıdır. Nicel açıdan ise, işin tamamlanması için belirlenmiş olan zaman kısa ise iş yükü ağır, zaman fazla ise iş yükü daha hafif olarak değerlendirilecektir (Cam, 2004; Çelik, 2016).

Aşırı iş yüküne yönelik literatür incelendiğinde, çalışanların iş yükü seviyeleri ile farklı değişkenler arasındaki ilişkilerin incelenmiş olduğu görülmektedir. Van ve Geurts (2001); Greenglass, Burke ve Riksenbaum (2001) çalışmalarında, aşırı iş yüküne maruz kalan çalışanların tükenmişlik sendromu yaşadığını ortaya koymaktadırlar. Hancock ve Verwey (1997) ile Dorrian ve arkadaşları (2011) yapmış oldukları çalışmalarında, aşırı iş yüküne maruz kalan çalışanlarda fiziksel yönden güçsüzlüğün ve yorgunluğun ortaya çıktığını belirtmiştir.

Aşırı iş yükünün çalışan üzerindeki etkilerine yönelik yapılan çalışmalarda daha çok stres boyutu incelenmiştir (Mazloum ve diğerleri, 2008; Gümüştekin ve Öztemiz, 2004; Maslach ve Leiter, 2009). Nirel ve arkadaşları (2008), sağlık hizmetleri alanında yapmış oldukları çalışmada iş tatminsizliğinin tükenmişliğe neden olduğunu, iş tatminsizliğinin ve tükenmişliğin ise aşırı iş yükünden kaynaklı olarak ortaya çıtığını ifade etmişlerdir. Hakanen ve arkadaşları (2008) da diş hekimlerine uyguladıkları çalışmalarının neticesinde aşırı iş yükünün çalışanlar arasında tükenmeye ve bununla birlikte bireylerin sağlığında bozulmaların ortaya çıkmasına sebep olduğu sonucuna varmışlardır. Bireylerin iş yükleri arttıkça işten sağladıkları doyumun azaldığını (Cole, Panchanadeswaran ve Daining, 2004; Chou ve Robert, 2008; Jones, Chonko, Rangarajan ve Roberts, 2007) ve işten ayrılma niyetini artırdığını ortaya koyan çalışmalar (Shantz ve diğerleri, 2016; Çalışkan ve Bekmezci, 2019).

$H_{1}$ : Aşır iş yükü iş tatmini etkilemektedir.

\section{2. Örgütsel Bă̆lılık Kavramı}

Genel olarak bağlılık kavramı incelendiğinde, bağlılığın bireyin davranışına yön veren bir güç ve psikolojik bir bağ olduğu ileri sürülmektedir (Meyer ve Herscovitch, 2001). Örgütsel bağlılık, çalışanın örgüt çıkarlarını kendi çıkarlarından daha üstün şekilde görerek buna uygun şekilde davranması olarak da ifade edilmektedir (Baysal ve Paksoy, 1999). Bireyin, kurumun ideallerine güvenmesi, büyük çaba harcaması ve çalıştığı kurumunda kalmayı arzu etmesini gerektirmektedir (Dunham ve diğerleri, 1994).

Allen ve Meyer (1991), örgütsel bağllı̆̆ğın; duygusal bağllılı, devam bağlılığı ve normatif bağl1lık bileşenlerinden oluştuğunu belirtmektedirler. Duygusal bağlılık, bir organizasyonda görev yapan bireylerin duygusal yönden kendi istekleri ile organizasyonda kalma arzusudur. Örgütsel bağlllı̆ı̆n bu boyutu, bireyin örgüt bünyesinde kalmayı kendisinin istemesi nedeniyle, bütün boyutlar arasında örgütler tarafından en çok arzu edilen durum olarak ifade edilmektedir (Ada, Alver ve Atlı 2008). Bir diğer bileşen ise devam bağlılığ1 olup, örgütte görevli olan çalışanın örgütten vazgeçmesi sonucunda oluşabilecek kayıpların değerlendirilmesi sonucu göstermiş olduğu bağl1lık olarak ifade edilmektedir. Buna göre devam bağlllığı, çalışanların örgütte görev yaptığı süre içerisinde harcamış olduğu her türlü zaman, çaba ve emeğin yanı sıra kazanmış olduğu birtakım haklar, kıdem, terfi imkanları ile birlikte maddi imkanlarını örgütten ayrılması durumunda kaybedeceği ve kaybedilen bu faydaların başka bir örgütlerde çalışma durumunda dahi yeniden kazanamayacağı fikrine sahip olmalarıdır (Boylu, Pelit ve Güçer,2008). Son bileşen ise normatif bağlılık olup, çalışan bireylerin örgüte olan sadakati ve ahlaki değerleri nedeniyle örgütteki görevlerine devam etmek istemeleri ve bunun sonucunda göstermiş oldukları bağlllıktır. Normatif bağlılık düzeyi diğerlerine göre daha yüksek olan bireyler, görev aldığı örgütün kendisine vermiş olduğu imkanlardan dolayı bir sadakat duygusu ile hareket ederler. Çalışanların çalıştıkları kurumla olan bağını güçlendiren örgütsel bağ kuvvetli olduğu zaman bu bağ çalışanın kurumdan ayrılmasına engel olabilmektedir (Derin ve Demirel, 2012). Çalıştığı örgüte bağlı bir birey, örgütü etkisi altına alan olası bir olumlu ya da olumsuz durumda örgütte kalan bireydir. Bunun yanı sıra destekleyici bir çalışma ortamı ve organizasyonda görev alan personeli güçlendirmeyi hedefleyen programlar gibi örgütün kendi çalışanlarına sağladığı fırsatlar, çalışanın görev yaptığı organizasyona olan bağlılığını da arttırmaktadır. Verimliliği yüksek olan bir çalışanın örgütte kalması örgütsel verimlilik oranında artışı sağlamakta olup, çalışanın örgütteki görevine devam etmesinin sağlanması örgüt yöneticileri için yüksek öncelikli olmaktadır (Northcraft ve Neale, 1990). Organizasyonlar, eğer başarılı bir şekilde görev yapmak, rekabet avantajını elinde bulundurarak varlıklarını devam ettirmek istiyorlarsa çalışanlarının bağlılıklarının sağlanması konusuna büyük önem vermeleri gerekmektedir (İnce ve Gül, 2005). 


\section{F. Mansur - F. Seyhan 13/2 (2021) 1033-1049}

Sağlık kurumları açısından değerlendirildiğinde, bir çalışanın kurum ve hedefleriyle ne ölçüde özdeşleştiği ve örgütsel üyeliği sürdürme arzusu olarak tanımlanan örgütsel bağlllık, hastanelerin örgütsel etkinliğini artırmada önemli bir faktör olabilmektedir (Becton vd., 2009). Sağlik hizmeti sunumunda görev alan çalışanların organizasyona olan bağlılıkları diğer organizasyonlarla kıyaslandığında sağlık kurum ve kuruluşlarında sunulan hizmetin direkt olarak insan hayatı ve sağlığı ile ilgili olması önemini daha da arttırmaktadır.

Örgütsel bağlllık çalışmalarında örgütsel bağlllığın; örgütsel adalet, iş tatmini, liderlik tarzları, iş stresi, örgütsel güven, örgütsel vatandaşlık, personeli güçlendirme, örgütsel performans, işten ayrılma niyeti gibi değişkenlerle olan ilişkisi incelenmiştir (Yüksel, 2003; Tutar, 2007; Karahan, 2009; Berberoglu, 2018; Ocak vd., 2012; Becton vd. 2009; Altindis, 2011; Gutierrez vd., 2012; Azeem ve Akhtar, 2014; Sundaram, 2016; Tumba, 2019). Çalışma sonuçlarına göre örgütsel bağlllık ile güven, performans, tatmin, motivasyon, adalet ve personeli güçlendirme arasında pozitif yönlü; örgütsel stres, aşırı iş yükü, tükenmişlik, örgütsel çatışma ve işten ayrılma niyeti arasında negatif yönlü ilişkinin bulunduğu görülmüştür.

$H_{2}$ : Aşır iş yükü örgütsel bağhllı̆̆ı etkilemektedir.

H.1: Aşır iş yükü duygusal bă̆gllı̆̆ı etkilemektedir.

$H_{2.2:}$ Aşııı iş yükü devamlılık bağhllı̆̆ını etkilemektedir.

$H_{2.3:}$ Aşırı iş yükü normatif bağglllı̆̆ı etkilemektedir.

\section{3. İş Tatmini Kavramı}

Entelektüel sermayenin bir unsuru olarak kabul edilen insan gücü kurumların rekabetçi konumlarını korumalarında işletmeye değer katan önemli bir kaynak olarak görülmektedir. Kurumların sahip olduğu fiziki şartlar, teknoloji, alt yapı gibi maddi kaynakları ne kadar iyi olursa olsun bunların etkin ve verimli kullanılmasını sağlayan insan kaynağı olduğu unutulmamalıdır (Bingöl, 2014). Neo-klasik yaklaşım olarak bilenen ve 1920'lerde, Elton Mayo ve arkadaşlarının, Hawthorne Araştırması sonuçları insan faktörünün önemini ortaya koymuş; çalışanların fizyolojik, psikolojik ve ekonomik unsurlarının iş verimliliğine etkisi ile birlikte iş tatmini konusu gündeme gelmeye başlamıştır (Mayo, 1945).

İş tatmininin tanımını literatüre ilk defa kazandıranların arasında ilk sıralarda yer alan Locke (1976) iş tatminini, "çalışanın kendi işini değerlendirmesi sonucunda ortaya çıkan pozitif duygusal durum ya da memnuniyet" olarak tanımlamıştır. İşletmedeki üretim düzeyini maksimuma çıkarma koşullarının başında gelen iş tatmini; bir çalışanın çalıştığı kurumda psikolojik olarak kendisini huzurlu ve mutlu hissetmesine, bunun karşıllğında iş yerindeki performansının artmasına, işten ayrılma niyetinin azalmasına ve çalıştığı kuruma sadık kalmasına yarayan en önemli motive unsurudur. İş tatmini veya işinden duyduğu memnuniyet duygusunun çalışan için çok büyük bir motivatör olduğu yapılan birçok çalışmada ortaya konmuştur (Brief ve Howard, 2002).

Sağlık sektörü, tıbbi teknolojideki ilerlemenin ve daha sofistike hasta bakımına olan talebin bir sonucu olarak bugün daha yetenekli bir işgücüne ihtiyaç duymaktadır. Sağlık çalışanları arasındaki iş tatmini, giderek artan bir şekilde önem kazanmakta ve kalite geliştirme tekniklerinde önem verilmesi gereken konuların arasında ilk sırada yer almaktadır. Sağlık sektöründeki iş tatminsizliği sağlık hizmetlerini aksatacak derecede işgücü devir oranının artmasına ve çalışanların yüksek oranda devamsızlığına neden olmaktadır (Ramasodi, 2010).

İş tatminine etki eden faktörler; fiziksel çalışma ortamının uygun olması, stressiz bir çalışma ortamının teminatını sağlayan yönetim tarzı, çalışma koşulları (Erdil vd., 2004), yöneticilik faktörü, çalışanlara profesyonel gelişim imkanı sağlanması, yöneticiden gelen olumlu geri bildirim ve destek (Unni vd., 2000) başta gelen unsurlar olarak değerlendirilmiştir.

İş tatmini konusunda literatür incelendiğinde; iş tatmini ile örgütsel bağlllık (Feather ve Rauter, 2004; Lok ve Crawford, 2004; Lum, Kervin, Clark, Reid ve Sirola, 1998; Rusu,2013; Testa, 2001; Eslami ve Gharakhan, 2012; Hazriyanto ve Badaruddin.2019); iş tatmini ve yaşam doyumu (Judge, Bono, Erez ve Locke, 2005; Judge ve Watanabe, 1993; Tait, Padgett ve Baldwin, 1989) arasında pozitif bir ilişkisinin olduğu görülmektedir. Çalışanlarına iş tatmini sağlayan örgütlerin, küresel çapta daha başarılı oldukları; örgütte işgücü devir oranının düşmesine imkan sağlayarak, çalışanlarının örgütsel bağlılık, iş verimliliği, üretkenlik, sahiplenme duyguları üzerinde olumlu etki oluşturmaktadır (Folger ve Konovsky, 1989). Li ve diğerleri (2019) tarafından 
yapılan çalışma, iş yükü ile iş tatmini arasında ters yönde, işten ayrılma niyeti ile pozitif yönde bir ilişkinin bulunduğunu göstermektedir.

H3: İş tatmini örgütsel bağhllı̆̆ı etkilemektedir.

H.1: İş tatmini duygusal bağhllı̆̆ı etkilemektedir.

H3.2: Işs tatmini devamlılık bağgllı̆̆ını etkilemektedir.

$H_{3.3:}$ İs tatmini normatif bağhlılı̆̆ etkilemektedir.

\section{Yöntem}

\subsection{Araştırma Modeli}

Teorik çerçeve kapsamında geliştirilen hipotezler doğrultusunda oluşturulan araştırma modeli Şekil 1'de verilmiştir.

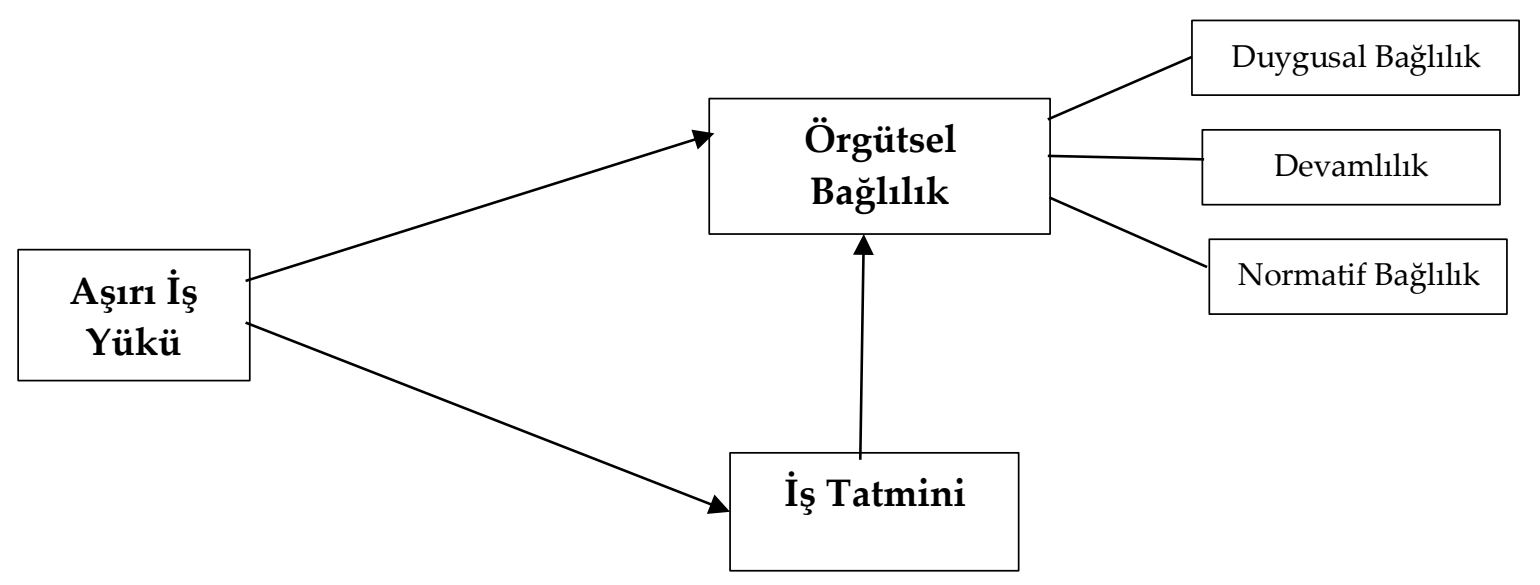

Şekil 1. Araştırma Modeli

\subsection{Evren ve Örneklem}

Çalışmada kişisel dozimetre taşıyan çalışanlarda aşırı iş yükünün örgütsel bağlılık ve iş tatmini üzerindeki etkisi belirlenmek amacıyla betimsel araştırma yöntemi kullanılmıştır. Çalışmanın evrenini Ankara ilinde faaliyet gösteren kamu ve özel sağlık kuruluşlarında görevli olup kişisel dozimetre taşıyan çalışanlar oluşturmaktadır. Hastanelerin radyoloji, nükleer tıp, radyasyon onkolojisi, ameliyathaneler, kalp damar cerrahisi, gastroenteroloji, üroloji, ortopedi, kardiyoloji, acil, genel cerrahi, göğüs hastalıkları kliniklerinde (kişisel dozimetre taşıyan doktor, hemşire, tekniker, teknisyen gibi sağlık çalışanlarının yanı sıra yine kişisel dozimetre taşıyan temizlik personeli, tıbbi sekreter ya da raportörler de dahil olmak üzere) çalışan bireyler araştırmaya dahil edilmiştir.

\subsection{Veri Toplama Arace}

Araştırmanın verileri elde etmek amacıyla anket tekniğinden yararlanılmıştır. Anket dört bölümden oluşmaktadır. Birinci bölümünde katılımcıların demografik özelliklerini belirlemeye yönelik sorular bulunmaktadır. İkinci bölümde; katılımcıların aşırı iş yükü düzeyini ölçmek amacıyla; Peterson vd. (1995) tarafından geliştirilen, Derya (2008) tarafından Türkçe'ye uyarlanan geçerliliği ve güvenilirliği test edilmiş, tek boyut 11 maddeden oluşan "Aşırı İş Yükü Ölçeği", üçüncü bölümde; örgütsel bağlıllı̆ı ölçmeye yönelik Meyer ve Allen (1991) tarafından geliştirilen Baysal ve Paksoy (1999) tarafından Türkçe'ye uyarlanan duygusal bağlılık, devamlılık bağlılığı ve normatif bağlılık olarak gruplandırılmış üç boyutlu 18 maddeden oluşan "Örgütsel Bağlılık Ölçeği”, dördüncü bölümde ise katılımcıların iş tatmin düzeylerini ölçmeye yönelik Hackman ve Oldham (1975) tarafından geliştirilen, Basım ve Şeşen (2009) tarafından geçerlilik ve güvenilirliği test edilmiş olan “İş Özellikleri Anketi"nden uyarlanan 5 madde kullanılmıştır. Araştırmanın verileri anketlerin katılımcılara online olarak uygulanmasıyla elde edilmiştir. 


\subsection{Verilerin Analizi}

Online olarak uygulanan anket sonucu elde edilen veriler SPSS programı ile analiz edilmiştir. Analiz sonucu veriler normal dağılım gösterdiğinden $(\mathrm{p}>0.005)$ parametrik testler uygulanmıştır. Araştırmada öncelikle katılımcıların demografik özelliklerini belirlemek amacıyla frekans dağılımları alınmıştır. Demografik değişkenler ile ilişkiyi belirlemek amacıyla $\mathrm{T}$ testi ve Anova testi yapılmıştır. Değişkenler arasındaki ilişkinin varlığını ve değişimin yönünü belirlemek amacıyla da Korelasyon analizi yapılmıştır.

\section{Bulgular}

Araştırmadan elde edilen bulgular bu bölümde yer almakta olup katılımcılara ait tanımlayıcı bulgular, araştırmada kullanılan ölçeklerin geçerlilik ve güvenilirlik analizlerine ilişkin bulguların yanı sıra aşırı iş yükü, örgütsel bağlllık ve iş tatminine yönelik yapılan analizlere ilişkin bulgular da bu bölümde verilmiştir.

\subsection{Katılımcıların Kişisel Bilgilerine İlişkin Bulgular}

Araştırmaya 191 katılımcı dahil olmuştur. Katılımcıların \%57,6's1 erkek, \%66'sı evli, \%45'i 36-45 yaş arası, $\% 40,3$ 'ü ön lisans mezunudur. Katılımcıların \%19,9 'unun hizmet yılı aralığı 1-5 iken, gelir durumu 5001 TL ve üzeri olanların oranı $\% 39,8$ ve $4001-5000$ TL arası olanların ise $\% 37,2^{\prime}$ dir. Teknisyen olarak görev yapanların oranı \% 84,8 ve aldığı ücretin işinin karşılığı olduğunu düşünmeyenlerin oranı ise $\% 73,8^{\prime}$ dir.

\subsection{Güvenilirlik Analizine İlişkin Bulgular}

Tablo 1. Güvenilirlik Analizine İlişkin Bulgular

\begin{tabular}{lcc}
\hline \multicolumn{1}{c}{ Boyutlar } & Cronbach' Alpha & İfade sayısı \\
\hline Aşırı iş yükü analizi & 0,85 & 10 \\
\hline Duygusal bağlılık & 0,71 & 5 \\
\hline Devamlılık bağlılığı & 0,76 & 6 \\
\hline Normatif bağlılık & 0,82 & 5 \\
\hline Örgütsel bağllılk (tüm boyutlar) & 0,84 & 16 \\
\hline İş tatmini & 0,90 & 5 \\
\hline
\end{tabular}

Ölçeklerde yer alan ifadelerin aynı yapıyı ölçüp ölçmediği, diğer bir ifade ile kendi içerisinde tutarlı bir ilişki içerisinde olup olmadığını belirlemek amacıyla yapılan güvenilirlik analizi sonuçları Tablo 1'de verilmiştir. Örgütsel bağlılık ölçeği için güvenilirlik analizi ilk olarak her boyut için ayrı ayrı uygulanmıştır. Çünkü Cronbach Alfa değeri örneklem ve ifade sayısı ile birlikte yükselme eğilimi gösterdiğinden bütünden çok faktör düzeyindeki sonuçlar daha hassas görülmektedir (Yaşlığlu, 2017). Buna göre her bir ölçeğe ilişkin Cronbach Alfa katsayısı sosyal bilimler için geçerli olan 0,70'in üzerindedir. Ölçeklerin güvenilir olduğu görülmektedir.

\subsection{Değişkenlerin Analizine İlişkin Bulgular}

Değişkenlere tanımlamaya yönelik ifadelerin söz konusu değişkeni temsil edip etmediğini belirlemek amacıyla yapılan tek boyutluluk analizi yapılmıştır. Yapılan analiz sonucunda faktör yükü 0,40'ın altında olan ifadeler ölçeklerden çıkarılmıştır (Aşırı İş Yükü Ölçeği 8 nolu ifade, Örgütsel Bağlılık Ölçeği 3 ve 13 nolu ifadeler). Ölçeklerden ifadeler çıkarıldıktan sonra tek boyutluluk analizi tekrar yapılmış ve faktör yükü $0,40^{\prime} ı n$ altında olan herhangi bir madde olmadığı görülmüştür. 
F. Mansur - F. Seyhan 13/2 (2021) 1033-1049

Tablo 2. Değişkenlere İlişkin Ortalamalar

\begin{tabular}{lcc}
\hline Değişkenler & $\overline{\boldsymbol{X}}$ & s.s \\
\hline Aşırı iş yükü & 3,14 &, 87175 \\
\hline Duygusal bağlılık & 3,10 &, 83699 \\
\hline Devamlılık bağlılı̆̆ı & 3,30 &, 77742 \\
\hline Normatif bağlılık & 3,11 &, 92342 \\
\hline Örgütsel bağlılık (genel) & 3,18 &, 64873 \\
\hline İş tatmini & 3,25 & 1,00817 \\
\hline
\end{tabular}

Değişkenlere ilişkin ortalamaların bulunduğu yukarıda verilmiş olan Tablo 2 incelendiğinde, katılımcıların devamlılık bağlılığı ve iş tatmini ortalamalarının diğer ortalamalardan daha yüksek olduğu görülmektedir. Genel olarak bakıldığında aşırı iş yükü, örgütsel bağlılık ve iş tatmini ortalamalarının birbirine yakın değerlerde olduğu görülmektedir.

Tablo 3. Aşırı İş Yükünün Örgütsel Bağlllığa Etkisi

\begin{tabular}{lccccc}
\hline Değişken & $\mathbf{B}$ & $\mathbf{S H}$ & $\boldsymbol{\beta}$ & $\mathbf{t}$ & $\mathbf{p}$ \\
\hline Örgütsel bağlllık (Sabit) & 2,900 &, 175 & & 16,545 &, 00 \\
\hline Aşırı iş yükü &, 090 &, 054 &, 121 & 1,674 &, 09 \\
\hline
\end{tabular}

$\mathrm{R}^{2}=0,01$; Düzeltilmiş $\mathrm{R}^{2}=0,01 ; \mathrm{F}(1,189)=2,802, \mathrm{p}>0,01$

Tablo 3'te aşırı iş yükünün örgütsel bağlllığa etkisini belirlemek amacıyla yapılan basit doğrusal regresyon analizi sonuçları verilmektedir. Analiz sonuçları istatistiksel olarak anlamlı bulunmamıştır $[\mathrm{F}(1,189)=2,802$, p>0,01]. Aşırı iş yükünün örgütsel bağl1lık üzerinde etkisi bulunmamaktadır ( $\mathrm{H}_{2}-K a b u l$ edilmedi).

Tablo 4. Aşırı İş Yükünün Duygusal Bağllı̆̆ga Etkisi

\begin{tabular}{lccccc}
\hline Değişken & B & SH & $\boldsymbol{\beta}$ & $\mathbf{t}$ & $\mathbf{p}$ \\
\hline Duygusal bağlllık (Sabit) & 3,395 &, 227 & & 14,970 &, 00 \\
\hline Aşırı iş yükü &,- 092 &, 070 &,- 096 & $-1,328$ &, 18 \\
\hline
\end{tabular}

$\mathrm{R}^{2}=0,00$; Düzeltilmiş $\mathrm{R}^{2}=0,00 ; \mathrm{F}(1,189)=1,764, \mathrm{p}>0,01$

Tablo 4'te aşırı iş yükünün örgütsel bağlılık boyutlarından duygusal bağlılık üzerinde anlamlı etkisinin bulunmadığı görülmektedir $[\mathrm{F}(1,189)=1,764, \mathrm{p}>0,01]$. Buna göre $\mathrm{H}_{2.1}$ hipotezi kabul edilmemiştir.

Tablo 5. Aşırı iş yükünün devamlılık bağ lılığına etkisi

\begin{tabular}{lccccc}
\hline Değişken & B & SH & $\boldsymbol{\beta}$ & $\mathbf{t}$ & $\mathbf{p}$ \\
\hline Devamlılık Bağlllı̆̆ı (Sabit) & 2,553 &, 204 & & 12,520 &, 00 \\
\hline Aşırı İş yükü &, 239 &, 063 &, 268 & 3,819 &, 00
\end{tabular}

$\mathrm{R}^{2}=0,07$; Düzeltilmiş $\mathrm{R}^{2}=0,06 ; \mathrm{F}(1,189)=14,588, \mathrm{p}<0,01$

Tablo 5 'te aşırı iş yükünün örgütsel bağlllık boyutlarından devam bağlllığı üzerine etkisini belirlemek amacıyla yapılan analiz sonucunda aşırı iş yükünün devam bağlılığına anlamlı etkisinin bulunduğu görülmüştür $[F(1,189)=12,520, p<0,01]$. Tablo değerlerinden Düzeltilmis $R^{2}$ değeri 0,06 'dır. Aşırı iş yükü devam bağlılığını \%6 etkilemektedir ( $\mathrm{H}_{2.2}$ kabul edildi). 
F. Mansur - F. Seyhan 13/2 (2021) 1033-1049

Tablo 6. Aşırı İş Yükünün Normatif Bağlllı̆̆a Etkisi

\begin{tabular}{lccccc}
\hline Değişken & B & SH & $\boldsymbol{\beta}$ & $\mathbf{t}$ & $\mathbf{p}$ \\
\hline Normatif Bağlllık (Sabit) & 2,823 &, 250 & & 11,273 &, 00 \\
\hline Aşırı İş yükü &, 094 &, 077 &, 088 & 1,220 &, 22 \\
\hline
\end{tabular}

$\mathrm{R}^{2}=0,00 ;$ Düzeltilmiş $\mathrm{R}^{2}=0,00 ; \mathrm{F}(1,189)=1,489, \mathrm{p}>0,01$

Tablo $6^{\prime}$ da aşırı iş yükünün normatif bağlılığa etkisini belirlemek amacıyla yapılan regresyon analizi sonucunda istatistiksel olarak anlamlı etki görülmemiştir $[\mathrm{F}(1,189)=1,489, \mathrm{p}>0,01]$. Bu sonuca göre $\mathrm{H}_{2.3}$ kabul edilmemiştir.

Tablo 7. Aşırı İş Yükünün İş Tatminine Etkisi

\begin{tabular}{lccccc}
\hline Değişken & B & SH & $\boldsymbol{\beta}$ & $\mathbf{t}$ & $\mathbf{p}$ \\
\hline İş tatmini (Sabit) & 3,893 &, 270 & & 14,413 &, 00 \\
\hline Aşırı İş yükü &,- 204 &, 083 &,- 177 & $-2,470$ &, 01
\end{tabular}

$R^{2}=0,03$; Düzeltilmiş $R^{2}=0,02 ; F(1,189)=6,100, p<0,01$

Tablo 7' de aşırı iş yükünün iş tatminine etkisini belirlemek amacıyla yapılan regresyon analizi sonucunda aşırı iş yükünün iş tatminine etkisi istatistiksel olarak anlamlı bulunmuştur $[F(1,189)=6,100, p<0,01]$. Buna göre aşırı iş yükü iş tatminini negatif yönde ve \%2 etkilemektedir ( $\mathrm{H}_{1}$ kabul edildi).

Tablo 8. İş Tatmininin Örgütsel Bağlllığa Etkisi

\begin{tabular}{lccccc}
\hline Değişken & $\mathbf{B}$ & $\mathbf{S H}$ & $\boldsymbol{\beta}$ & $\mathbf{t}$ & $\mathbf{p}$ \\
\hline Örgütsel bağlllık (Sabit) & 2,009 &, 132 & & 15,245 &, 00 \\
\hline İş tatmini &, 361 &, 039 &, 562 & 9,332 &, 00
\end{tabular}

$\mathrm{R}^{2}=0,31$; Düzeltilmiş $\mathrm{R}^{2}=0,31 ; \mathrm{F}(1,189)=87,083, \mathrm{p}<0,01$

Tablo 8' de iş tatmininin örgütsel bağlllığa etkisi analiz edilmiştir. Basit doğrusal regresyon analizi sonucunda iş tatmininin örgütsel bağl1lı̆̆ı istatistiksel olarak anlamlı, pozitif ve \%31 oranında etkilediği görülmektedir $[\mathrm{F}(1,189)=87,083, \mathrm{p}<0,01]$. Bu sonuca göre $\mathrm{H}_{3}$ kabul edilmiştir.

Tablo 9. İş Tatmininin Duygusal Bağlllığa Etkisi

\begin{tabular}{lccccc}
\multicolumn{1}{c}{ Değişken } & B & SH & $\boldsymbol{\beta}$ & $\mathbf{t}$ & $\mathbf{p}$ \\
\hline Duygusal bağllikk(Sabit) & 1,570 &, 169 & & 9,290 &, 00 \\
& & & & & \\
\hline İş tatmini &, 472 &, 050 &, 569 & 9,508 &, 00 \\
\hline
\end{tabular}

$\mathrm{R}^{2}=0,32 ;$ Düzeltilmiş $\mathrm{R}^{2}=0,32 ; \mathrm{F}(1,189)=90,394, \mathrm{p}<0,01$

Tablo 9'da iş tatmininin örgütsel bağlllık boyutlarından duygusal bağlllığa etkisinin bulunduğu görülmektedir $[F(1,189)=90,394, p<0,01]$. Regresyon analizi sonucuna göre iş tatminini duygusal bağll1ı̆̆1 pozitif yönde ve $\% 32$ oranında etkilemektedir ( $\mathrm{H}_{3.1}$ kabul edilmiştir). 
F. Mansur - F. Seyhan 13/2 (2021) 1033-1049

Tablo 10. İş Tatmininin Devamlılık Bağlılığına Etkisi

\begin{tabular}{lccccc}
\multicolumn{1}{c}{ Değişken } & B & SH & $\boldsymbol{\beta}$ & $\mathbf{t}$ & $\mathbf{p}$ \\
\hline Devamlılık bağlılığı (Sabit) & 2,898 &, 188 & & 15,388 &, 00 \\
& & & & & \\
\hline İş tatmini & 125 &, 055 &, 162 & 2,256 &, 02
\end{tabular}

$\mathrm{R}^{2}=0,02 ;$ Düzeltilmiş $\mathrm{R}^{2}=0,02 ; \mathrm{F}(1,189)=5,091, \mathrm{p}>0,01$

Tablo 10'da iş tatmininin örgütsel bağllık boyutlarından devamlılık bağlllığına etkisinin istatistiksel olarak anlamlı bulunmadığı görülmektedir $\left[\mathrm{F}(1,189)=5,091\right.$, p>0,01]. Buna göre $\mathrm{H}_{3.2}$ kabul edilmemiştir.

Tablo 11. İş Tatmininin Normatif Bağlllığa Etkisi

\begin{tabular}{lccccc}
\multicolumn{1}{c}{ Değişken } & B & SH & $\boldsymbol{\beta}$ & t & p \\
\hline Normatif bağlllık(Sabit) & 1,380 &, 184 & & 7,498 &, 00 \\
& & & & & \\
\hline İş tatmini &, 534 &, 054 &, 583 & 9,875 &, 00
\end{tabular}

$\mathrm{R}^{2}=0,34$; Düzeltilmiş $\mathrm{R}^{2}=0,33 ; \mathrm{F}(1,189)=97,520, \mathrm{p}<0,01$

Tablo 11'de iş tatmininin örgütsel bağlılık boyutlarından normatif bağlılığa etkisi istatistiksel olarak anlamlı bulunmuştur $[F(1,189)=97,520, p<0,01]$. Yapılan regresyon analizi sonucunda iş tatmininin normatif bağlllı̆̆ pozitif yönde ve \%33 etkilediği görülmektedir ( $\mathrm{H}_{3.3}$ kabul edilmiştir).

\subsubsection{Aşın İş Yüküne İlişkin Analizler}

Cinsiyet ile aşırı iş yükü arasında istatistiksel olarak anlamlı farklılık bulunamamıştır ( $p>0,05)$.

Medeni durum ile aşırı iş yükü arasında istatistiksel olarak anlamlı farklılık bulunamamıştır $(p>0,05)$.

Hizmet yılı ile aşırı iş yükü arasında istatistiksel olarak anlamlı farklılık bulunamamıştır $(p>0,05)$.

Eğitim durumu ile aşırı iş yükü arasında istatistiksel olarak anlamlı farklılık bulunamamıştır ( $p>0,05)$.

Yaş ile aşırı iş yükü arasında istatistiksel olarak anlamlı farklılık bulunamamıştır ( $p>0,05)$.

Gelir düzeyi ile aşırı iş yükü arasında istatistiksel olarak anlamlı farklılık bulunamamıştır ( $p>0,05)$.

Tablo 12. Görev ile Aşırı İş Yükü Arasındaki Farklılık

\begin{tabular}{|c|c|c|c|c|c|c|c|}
\hline & & $\mathbf{n}$ & $\bar{X}$ & s.s. & $\mathbf{F}$ & $\mathrm{p}$ & Farklılık \\
\hline \multirow[t]{3}{*}{ Görev } & Doktor & 12 & 3.75 & ,71795 & \multirow{3}{*}{7.172} & \multirow{3}{*}{.00} & \multirow{3}{*}{$\begin{array}{c}\text { Teknisyen ile } \\
\text { Doktor } \\
\text { Hemşire }\end{array}$} \\
\hline & Hemşire & 17 & 3,64 & ,97540 & & & \\
\hline & Teknisyen & 162 & 3,04 & ,83875 & & & \\
\hline
\end{tabular}

Tablo 12 incelendiğinde katılımcıların aşırı iş yükünün hastanedeki görevlerine göre farklılaştı̆̆ı görülmektedir. Aşırı iş yükü ortalamalarına göre doktor ve hemşirelerin iş yükleri teknisyenlere göre daha fazladir.

Tablo 13. Alınan Ücretin İşinin Karşılığı Olduğunu Düşünme İle Aşırı İş Yükü Arasındaki Farklılık

\begin{tabular}{llccccc}
\hline & & $\mathbf{n}$ & $\overline{\boldsymbol{X}}$ & s.s. & $\mathbf{t}$ & $\mathbf{P}$ \\
\hline $\begin{array}{l}\text { Aldığınız ücretin işinizin karşılığı } \\
\text { olduğunu düşünüyor musunuz }\end{array}$ & Evet & 50 & 2,08 &, 78268 & $-4,307$ \\
\cline { 2 - 6 } & Hayır & 141 & 3,29 &, 85134 & $-4,484$ \\
\hline
\end{tabular}




\section{F. Mansur - F. Seyhan 13/2 (2021) 1033-1049}

Tablo 13'te katılımcıların almış oldukları ücretin yaptıkları işin karşlığı olduğunu düşünüp düşünmeme durumları ile aşırı iş yüküne sahip olduklarını düşünmeleri arasında istatistiksel olarak anlamlı farklılık bulunup bulunmadığını belirlemeye yönelik yapılan analiz sonuçları yer almaktadır. Buna göre aldığı ücretin yaptı̆̆ işin karşılığı olduğunu düşünmeyenlerin aşırı iş yükü ortalamalarının $(\bar{X}=3,29)$ daha yüksek olduğu görülmektedir. Aşırı iş yükü olduğunu düşünen katılımcılar, aldıkları ücretin yaptıkları işin karşılığı olmadığı görüşündedir.

\subsection{2. Örgütsel Bă̆lılı̆̆a İlişkin Analizler}

Cinsiyet ile örgütsel bağlılık boyutları ve örgütsel bağlılık arasında istatistiksel olarak anlamlı farklılık bulunamamıştır ( $>>0,05)$.

Medeni durum ile örgütsel bağllık boyutları ve örgütsel bağlılık arasında istatistiksel olarak anlamlı farklılık bulunamamıştır ( $p>0,05)$.

Hizmet yılı ve örgütsel bağlılık boyutları ve örgütsel bağlllık arasında istatistiksel olarak anlamlı farklılık bulunamamıştır ( $\mathrm{p}>0,05)$.

Eğitim durumu ile örgütsel bağlılık boyutları ve örgütsel bağlılık arasında istatistiksel olarak anlamlı farklılık bulunamamıştır ( $\mathrm{p}>0,05)$.

Görev ile örgütsel bağlılık boyutları ve örgütsel bağlılık arasında istatistiksel olarak anlamlı farklılık bulunamamıştır $(\mathrm{p}>0,05)$.

Tablo 14. Örgütsel Bağlılığın (Genel) Yaş Durumuna Göre Farklıllı̆̆

\begin{tabular}{|c|c|c|c|c|c|c|c|}
\hline & & n & $\overline{\boldsymbol{X}}$ & s.s. & $\mathbf{F}$ & $\mathrm{p}$ & Farklılık \\
\hline \multirow[t]{4}{*}{ Yaş } & 25 ve altı & 40 & 3.17 & 60658 & \multirow{4}{*}{2,939} & \multirow{4}{*}{0,03} & \multirow{4}{*}{$\begin{array}{r}26-35 \text { arası ile } \\
36-45 \text { arası }\end{array}$} \\
\hline & 26 ve 35 aras1 & 43 & 3.40 & .52546 & & & \\
\hline & 36 ve 45 aras1 & 86 & 3.05 & .68100 & & & \\
\hline & 46 ve üzeri & 22 & 3.25 & .72357 & & & \\
\hline
\end{tabular}

Örgütsel bağlılı̆̆ın katılımcıların yaş gruplarına göre farklılaşıp farklılaşmadığını belirlemeye yönelik yapılan analiz sonucunda (Tablo 14), yaşa göre istatistiksel olarak anlamlı farklılık görülmektedir ( $<<0,05)$. Farklılığın hangi gruplardan kaynaklandığını belirlemek amacıyla Post Hoc testlerinden LSD testi uygulanmıştır ve yaş aralığı 26-35 arası olan katılımcılar ile 36-45 yaş arası olanların örgütsel bağlılıkları anlamlı farklılık yaratmaktadır. Ortalamalar incelendiğinde de 26-35 yaş arası olan katılımcıların $(\bar{X}=3,40)$ en yüksek, 36-45 yaş arası katılıcıların ise en düşük $(\bar{X}=3,05)$ örgütsel bağlılık düzeyine sahip olduğu görülmektedir.

Tablo 15. Gelir Durumu ile Örgütsel Bağlılık Boyutları ve Örgütsel Bağlllık (Genel) Arasındaki Farklılık

\begin{tabular}{|c|c|c|c|c|c|c|c|}
\hline & & $\mathbf{n}$ & $\overline{\boldsymbol{X}}$ & s.s. & $\mathbf{F}$ & p & Farklılık \\
\hline \multirow[t]{4}{*}{ Devamlılık Bağ lılığı } & $2300-3000 \mathrm{TL}$ & 25 & 3.48 & .44075 & \multirow{4}{*}{3,049} & \multirow{4}{*}{0,03} & \multirow{4}{*}{$\begin{array}{r}3001-4000 \text { ile } \\
4001-5000 \\
5001 \text { ve üzeri }\end{array}$} \\
\hline & 3001-4000 TL & 19 & 3.71 & .40001 & & & \\
\hline & 4001-5000 TL & 71 & 3.27 & .74980 & & & \\
\hline & 5001 ve üzeri & 76 & 3.17 & .91346 & & & \\
\hline \multirow[t]{4}{*}{ Normatif Bağlllık } & $2300-3000 \mathrm{TL}$ & 25 & 3.36 & .94988 & \multirow[t]{4}{*}{4,413} & \multirow[t]{4}{*}{0,00} & \multirow{4}{*}{$\begin{array}{r}2300-3000 \text { ile } \\
5001 \text { ve üzeri } \\
3001-4000 \text { ile } \\
4001-5000 \\
5001 \text { ve üzeri }\end{array}$} \\
\hline & 3001-4000 TL & 19 & 3.70 & .60871 & & & \\
\hline & 4001-5000 TL & 71 & 3.05 & .93221 & & & \\
\hline & 5001 ve üzeri & 76 & 2.94 & .91028 & & & \\
\hline
\end{tabular}


F. Mansur - F. Seyhan 13/2 (2021) 1033-1049

\begin{tabular}{|c|c|c|c|c|c|c|c|}
\hline \multirow{4}{*}{$\begin{array}{l}\text { Örgütsel Bağlılık } \\
\text { (Genel) }\end{array}$} & $2300-3000 \mathrm{TL}$ & 25 & 3.36 & 57988 & \multirow[t]{4}{*}{4,438} & \multirow[t]{4}{*}{0,00} & 2300-3000 ile \\
\hline & $3001-4000 \mathrm{TL}$ & 19 & 3.57 & 42368 & & & 5001 ve üzeri \\
\hline & 4001-5000 TL & 71 & 3.16 & .63346 & & & $\begin{array}{r}3001-4000 \text { ile } \\
4001-5000\end{array}$ \\
\hline & 5001 ve üzeri & 76 & 3.03 & .68563 & & & 5001 ve üzeri \\
\hline
\end{tabular}

Tablo 15'te katılımcıların gelir durumlarına göre örgütsel bağlllık boyutları ve örgütsel bağlılıklarındaki farklılık analiz edilmiştir. Katılımcıların gelir durumları ile örgütsel bağllı̆̆ın devamlılık ve normatif bağlılık boyutlarında ve genel örgütsel bağlllıkta istatistiksel olarak anlamlı farklılık görülmektedir $(p<0,05)$. Devamlılık bağlılığı boyutunda gelir durumu diğer gruplara göre düşük olan katılımcıların ortalamalarının daha yüksek olduğu söylenebilir.

Normatif bağllılık ve genel örgütsel bağlılık sonuçları benzerlik göstermektedir. Gelir durumu 2300-3000 TL ve 3001-4000 TL arasında olan katılımcıların bağlılık düzeylerinin daha yüksek olduğu görülmektedir. Normatif ve genel örgütsel bağlılık düzeyi en düşük olan katılımcı grubu 5001 ve üzeri geliri olan katılımcılardır (sırasıyla $\bar{X}=2,94 ; \bar{X}=3,03$ ).

Tablo 16. Alınan Ücretin İşinin Karşılığı Olduğunu Düşünme ile Örgütsel Bağlılık Boyutları Arasındaki Farklılık

\begin{tabular}{lcccccc}
\hline & $\begin{array}{c}\text { Aldığınız ücretin işinizin } \\
\text { karşılığı olduğunu } \\
\text { düşünüyor musunuz }\end{array}$ & $\mathbf{n}$ & $\overline{\boldsymbol{X}}$ & s.s. & $\mathbf{t}$ & $\mathbf{P}$ \\
\cline { 2 - 6 } $\begin{array}{l}\text { Devamlılık } \\
\text { bağlılığı }\end{array}$ & Evet & 50 & 3.04 & .95656 & $-2,768$ & $\mathbf{0 , 0 2}$ \\
\cline { 2 - 6 } & Hayır & 141 & 3.39 & 68412 & $-2,368$ & \\
\hline
\end{tabular}

Aldığı ücretin işinin karşılığı olduğunu düşünüp düşünmeyenlerin, örgütsel bağlılık boyutları ve genel örgütsel bağlılık durumları arasındaki farklılığı belirlemek amacıyla yapılan analiz sonucunda (Tablo 16), istatistiksel olarak anlamlı farklılık örgütsel bağllı̆̆ın devamlılık bağllğı boyutunda görülmüştür $(\mathrm{p}<0,05)$. Aldığı ücretin işinin karşılı̆̆ı olduğunu düşünmeyen katılımcıların devamlılık bağlılığı ortalamasının daha yüksek olduğu görülmektedir $(\bar{X}=3,39)$.

\subsection{3. İş Tatminine İlişkin Analizler}

Cinsiyet ile iş tatmini arasında istatistiksel olarak anlamlı farklılık bulunamamıştır $(p>0,05)$.

Medeni durum ile iş tatmini arasında istatistiksel olarak anlamlı farklılık bulunamamıştır ( $p>0,05)$.

Hizmet yılı ile iş tatmini arasında istatistiksel olarak anlamlı farklılık bulunamamıştır ( $p>0,05)$.

Yaş ile iş tatmini arasında istatistiksel olarak anlamlı farklılık bulunamamıştır ( $p>0,05)$.

Gelir durumu ile iş tatmini arasında istatistiksel olarak anlamlı farklılık bulunamamıştır $(p>0,05)$.

Alınan ücretin işin karşılığı olduğu düşünme ile iş tatmini arasında istatistiksel olarak anlamlı farklılık bulunamamıştır ( $p>0,05)$.

Tablo 17. Eğitim Durumu ile İş Tatmini Arasındaki Farklılık

\begin{tabular}{|c|c|c|c|c|c|c|c|}
\hline & & $\mathbf{n}$ & $\overline{\boldsymbol{X}}$ & s.s. & $\mathbf{F}$ & p & Farklılık \\
\hline \multirow[t]{4}{*}{ Eğitim durumu } & Lise & 16 & 3.86 & .57373 & \multirow{4}{*}{3,117} & \multirow{4}{*}{0,02} & \multirow{4}{*}{$\begin{array}{c}\text { Lise ile } \\
\text { Lisans, } \\
\text { Lisansüstü }\end{array}$} \\
\hline & Ön lisans & 77 & 3.33 & 1.03751 & & & \\
\hline & Lisans & 65 & 3.07 & .96409 & & & \\
\hline & Lisansüstü & 33 & 3.10 & 1.08523 & & & \\
\hline
\end{tabular}


Tablo 17 'de verilen ve katılımcıların eğitim durumları ile iş tatmini arasındaki farklılığı belirlemek amacıyla yapılan analiz sonucunda lise mezunu katılımcıların, diğer grup katılımcılarına göre iş tatmin düzeylerinin daha yüksek olduğu görülmektedir. Ön lisans, lisans ve lisansüstü mezunu katılımcıların iş tatmin düzeyleri lise mezunlarına göre daha düşüktür. Farklılığın hangi gruplardan kaynaklandığını belirlemek amacıyla yapılan LSD testi sonucunda, lise ile lisans; lise ile lisansüstü mezunlarının iş tatmin düzeyleri arasında farklılık görülmektedir.

\section{Sonuç ve Tartışma}

Sağlık sektöründe çalışanların daha verimli ve kaliteli hizmet sunabilmesi için güvenli bir iş ortamının bulunmasının yanı sıra iş tatmini ve örgütsel bağlılık düzeyinin yüksek olması gerekmektedir. Bu bağlamda araştırmadan elde edilen sonuçlar değerlendirildiğinde, aşırı iş yükü ile iş tatmini arasında ters yönde ilişkinin bulunduğuna yönelik veriler elde edilmiş olup buna göre, çalışmaya katılanların iş yükü düzeyleri arttığında iş tatmininde azalmanın meydana geldiği söylenebilir. Literatür incelendiğinde de araştırma bulguları ile uyumlu çalışmalar söz konusudur. İş yükü arttığında iş tatmini azalmaktadır ( Li ve diğerleri,2019; Nirel ve diğerleri, 2008; Cole, Panchanadeswaran ve Daining, 2004; Chou ve Robert; 2008; Jones ve diğerleri, 2007; Çalışkan ve Bekmezci, 2019; Kanbur, 2018)

Araştırmanın bulgularından biri de devamlılık bağlılı̆̆ı ve aşırı iş yükü arasında pozitif ve zayıf bir ilişkinin bulunmasıdır. Devamlılık bağlılığı çalışanın daha iyi şartlarda başka iş imkanının bulunmaması ve bir bakıma zorunluluktan dolayı ortaya çıkan bağllılı türüdür. Ancak duygusal ve normatif bağlllık boyutu ile iş tatmini arasında pozitif yönde ve orta düzeyde bir ilişkinin bulunduğu da görülmektedir. Çalışanların yaptığı işe yönelik sahip olduğu olumlu duygusal tepkiler ve düşünceler onlardaki iş tatmini duygusunu da artırmakta ve örgütte kendi istedikleri için kalmaya devam etmektedir.

Araştırmada örgütsel bağlllık ile iş tatmini arasında pozitif yönde ve orta düzeyde bir ilişki olduğu görülmüştür. Literatürde de örgütsel bağlılı̆̆ın artmasının, iş tatminini artırdığına dair benzer çalışmalar bulunmaktadır (Hoş ve Oksay, 2015; Jermsıttıparsert ve Uraırak, 2019; Top, 2012; Fulford, 2005; Sergeant ve Frenkel, 2000; Kim ve diğerleri, 2005). Örgütsel bağlllık boyutlarından duygusal bağlllık ile iş tatmini arasında bulunan pozitif ve orta düzeydeki ilişki, Tutar (2007) tarafından yapılan çalışma ile uyumludur. Eslami ve Gharakhan (2012) tarafından yapılan çalışmada da bu çalışmada olduğu gibi, örgütsel bağlılığın tüm boyutları ile iş tatmini arasında pozitif ve anlamlı bir ilişki bulmuştur. Chegini ve diğerlerinin (2019) hemşirelerde örgütsel bağl1lık, iş tatmini, örgütsel adalet ve öz-yeterlik ilişkisini belirlemek amacıyla 401 hemşire üzerinde yapmış oldukları çalışmada, hastane yöneticilerinin algılanan örgütsel adaletlerini geliştirmek ve böylelikle iş tatminini artırmak için stratejiler kullanarak hemşirelerin örgütsel bağlllığını artırabilecekleri önerisinde bulunmuştur

Çalışmada aldığı ücretin yaptığı işin karşılığı olduğunu düşünmeyenlerin aşırı iş yükü ortalamalarının daha yüksek olduğu görülmektedir. Başka bir ifadeyle aşırı iş yükü olduğunu düşünen katılımcılar, aldıkları ücretin yaptıkları işin karşılığı olmadığı görüşündedir. Aldığı ücretin işinin karşılığı olduğunu düşünmeyen katılımcıların devamlılık bağlılığı ortalamasının daha yüksek olduğu görülmekte olup bu katılımcılar aslında daha yüksek ücreti hak ettiklerini düşünmektedir ve kuruma olan bağlllıkları bir gerekliliktir. Dışarıdaki iş alternatiflerinin azlığı, işten ayrıldığı takdirde yaşantısının olumsuz yönde etkileneceğine yönelik düşünceleri bu katılımcıları örgütte tutmakta olup, hak ettiği ücreti verecek alternatiflerinin bulunması halinde bu çalışanların örgüte olan bağlllıklarının sonlanabileceği değerlendirilmektedir.

Çalışmada doktor ve hemşirelerin aşırı iş yüklerinin teknisyenlere göre daha fazla olduğu da elde edilen bir başka sonuçtur. Araştırmanın diğer bir sonucu da 26-35 yaş arası olan katılımcıların en yüksek örgütsel bağlılığa sahip olmasına karşın 36-45 yaş arası katılıcıların ise en düşük örgütsel bağlllık düzeyine sahip olduğudur. Gelir durumu daha düşük olan katılımcıların devamlılık bağlılığının -daha iyi iş imkanı bulunmayan, kurumdan ayrılmanın zor olduğunu düşünen katılımcıların bağlılık türü olarak düşünüldüğünde- daha fazla gelir elde eden katılımcılara oranla daha yüksek olduğu görülmüştür.

Sağlık işletmesinin mevcut pazarda varlığını sürdürmesi için rekabet üstünlüğünü kazandıracak ve bununla birlikte kar marjını arttıracak olan, belki de en önemli unsur olan insan kaynağının sadece işletmede var olması yeterli olmamakta, iş tatmininin sağlanarak, örgütsel bağlılı̆̆ının artırılarak işletmede kalmasının sağlanması 


\section{F. Mansur - F. Seyhan 13/2 (2021) 1033-1049}

gerekmektedir. Özellikle hastanelerin tıbbi görüntüleme birimlerindeki aşırı iş yükünün yanı sıra radyasyondan kaynaklı risklerinde varlı̆̆ı, ilgili birimlerde görev yapan personelde de birtakım kaygıları beraberinde getirmektedir. İyonize radyasyonun olumsuz sağlık etkileri bilinmekle birlikte, sağlik kuruluşlarının radyoloji, nükleer tıp, radyasyon onkolojisi, ameliyathaneler, kalp damar cerrahisi, gastroenteroloji, üroloji, ortopedi, kardiyoloji, acil tıp, genel cerrahi, göğüs hastalıkları gibi kliniklerde radyasyonla uğraşan sağlı profesyonellerinin yanı sıra bu birimlerde görev yapmakta olan temizlik personeli, tıbbi sekreter, raportör ya da güvenlik görevlisi gibi sağlık dışı hizmet sunan diğer personelin de aynı riske maruz kalabildiği, bu kapsamda sağlık kurumlarının yönetici ve birim sorumlularının gereken önlemleri almasının yanı sıra denetleyici mekanizmalarında ilgili birimlerde gerekli kontrolleri sağlaması büyük önem arz etmektedir. Bu noktadan hareketle yapılmış olan bu çalışmanın sonuçlarıyla ilişkilendirildiğinde; işletmelerde çalışanları olumsuz yönde etkileyen aşırı iş yükü ile birlikte emek ve teknoloji yoğun hizmet sunan sağlik kurumlarında iyonize radyasyona maruz kalmanın çalışan sağlığına verdiği zarar göz önünde bulundurulduğunda, ilgili birimlerde görev yapan personelin örgütüne olan bağlılığının azalmasının yanı sıra iş tatmininin de azalacağı ve bu doğrultuda daha iyi bir iş imkanı olduğunda işten ayrılma niyetinde olabileceği muhtemeldir. Hastanelerin gerek yöneticileri gerekse birim sorumluları tarafından kişisel dozimetre taşıyan çalışanların iş yükü düzeylerinin adil bir biçimde değerlendirilmesi, gereken önlemler ve düzenlemeler yapılarak iş tatmininin sağlanması ve örgütsel bağlılığının güçlendirilip işletmede kalması sağlanmalıdır. Başka bir ifadeyle, özellikle girdi ve çıktısında insan faktörü olan, çok riskli ve bütünleşik bir yapıya sahip olan sağlık örgütlerindeki çalışanların, stres ve çatışma ortamlarını minimize edecek, aşırı iş yükünün ortaya çıkmasını engelleyecek, işyerinde radyasyona maruz kalmayı en aza indirecek ya da ortadan kaldıracak ve bunun sonucu olarak da dozimetre taşıyan personelin verimlilik seviyelerini, iş yaşam kalitelerini, iş tatminlerini ve örgütsel bağlılıklarını arttırıcı bir atmosfer oluşturulabilmesi yönündeki tüm çabalar desteklenmeli ve tüm yasal önlemler alınmalıdır.

\section{Kaynakça}

Ada, N., Alver, İ., \& Atll, F. (2008). Örgütsel iletişimin örgütsel bağlllık üzerine etkisi: Manisa organize sanayi bölgesinde yer alan ve imalat sektörü çalışanları üzerinde yapılan bir araştırma, $E A B D, 8(2), 500-501$.

Adams, A. \& Bond, S. (2000). Hospital nurses job satisfaction, individual and organizational characteristics, Journal of Advanced Nursing, 32(3), 536-543.

Allen, N.J. \& Meyer, J.P. (1991). A three-component conceptualization of organizational commitment. Human Resource Management Review, 1(1), 61-89.

Alpay, İ. \& Gürdal Ş.O. (2019). Kişisel radyasyon dozlarının belirlenmesi yöntemleri, dozimetrelerin hazırlanması ve okunması. Demir, M, Radyofarmasötiklerin Üretiminde ve Klinik Kullanımında Radyasyon Korunması. Ankara: Türkiye Klinikleri, 73-8.

Altindis, S. (2011). Job motivation and organizational commitment among the health professionals: A questionnaire survey. African Journal of Business Management, 5(21),8601-8609.

Ardıç, K. \& Polatcı, S. (2009). Tükenmişlik sendromu ve madalyonun öbür yüzü: İşle bütünleşme. Erciyes Üniversitesi İktisadi ve İdari Bilimler Fakültesi Dergisi, 32, 21-46.

Azeem, S.M. \& Akhtar, N. (2014). The influence of work life balance and job satisfaction on organizational commitment of healthcare employees, International Journal of Human Resource Studies. 4(2). Doi:10.5296/ijhrs.v4i2.5667.

Balsak, H. (2014). Radyoloji Çalışanlarının Tanı Amaçlı Kullanılan Radyasyonun, Zararlı Etkileri Hakkında Bilgi, Tutum ve Davranışları, İnönü Üniversitesi Sağlık Bilimleri Enstitüsü, Yüksek Lisans Tezi, Malatya.

Baysal, A.C., \& Paksoy, M. (1999). Mesleğe ve örgüte bağlılığın çok yönlü incelenmesinde Meyer-Allen modeli", İstanbul Üniversitesi İ̧letme Fakültesi Dergisi, 28(1) , 7-15.

Becton, J.B., Matthews, M.C., Hartley, D.L. \& Whitaker, D.H. (2009). Using biodata to predict turnover, organizational commitment, and job performance in healthcare. International Journal of Selection and Assessment, 17(2), 189-202. 
Berberoglu, A. (2018). Impact of organizational climate on organizational commitment and perceived organizational performance: empirical evidence from public hospitals. BMC Health Serv Res, 18, 399

Bingöl, D. (2014). İnsan Kaynakları Yönetimi. İstanbul, Beta

Blakely, E. A., Kleiman, N. J., Neriishi, K., Chodick, G., Chylack, L. T., Cucinotta, F. A. \& Kanamoto, T. (2010). Radiation cataractogenesis: epidemiology and biology, Radiation Research, 173(5), 709-717

Boylu, Y., Pelit, E. \& Güçer, E. (2007). Akademisyenlerin örgütsel bağlllık düzeyleri üzerine bir araştırma, Finans Politik \& Yorumlar Dergisi, 44 (511), 55-74

Brief, A.P. \& Howard M.W. (2002). Organizational behavior: affect in the workplace. Annual Review of Psychology 53(1), 279-307.

Bulut, K. \& Soylu, B. (2009). Öğretim üyelerinin iş yükü seviyelerinin bir analitik model ile değerlendirilmesi: mühendislik fakültesinde bir uygulama. Erciyes Üniversitesi Fen Bilimleri Enstitüsü Dergisi, 25(1-2), 150167.

Cam, E. (2004). Çalışma yaşamında stres ve kamu kesiminde kadın çalışanlar. Uluslararası İnsan Bilimleri Dergisi, 1(1), 1-10.

Chegini, Z., Janati, A., Asghari-Jafarabadi, M. \& Khosravizadeh, O. (2019). Organizational commitment, job satisfaction, organizational justice and self-efficacy among nurses. Nurs Pract Today,6(2), 86-93.

Chou, R.J. \& Robert, S.A. (2008). Workplace support, role overload, and job satisfaction of direct care workers in assisted living. J Health Soc Behav., 49(2):208-222. doi: 10.1177/002214650804900207. PMID: 18649503.

Cole, D., Panchanadeswaran, S. \& Daining, C. (2004). Predictors of job satisfaction of licensed social workers. Journal of Social Service Research, 31(1), 1-12.

Çakıcı, A., Özkan, C. \& Akyüz, H. B. (2013). İş yükü yoğunluğunun, iş ve yaşam doyumuna etkisi üzerine otomotiv işletmelerinde bir araştırma. Cag University Journal of Social Sciences, 10(2), 1-27.

Çalışkan, A. \& Bekmezci, M. (2019). Aşırı iş yükünün işten ayrılma niyetine etkisinde iş tatmini ve yaşam tatmininin rolü, sağlık kurumu çalışanları örneği, Adıyaman Üniversitesi Sosyal Bilimler Enstitüsü Dergisi, 11(31),

Çelik, M. (2016). Tükenmişlik yaşam doyumu ve iş yükü ilişkisi: Denizli'de faaliyet gösteren muhasebe meslek mensupları üzerinde bir araştırma. Süleyman Demirel Üniversitesi İktisadi ve İdari Bilimler Fakültesi Dergisi, 21(4), 1139-1152.

Derin, N. \& Demirel, E.T. (2012). Tükenmişlik sendromunun örgütsel bağlllığı zayıflatıcı etkilerinin malatya merkez'de görev yapan hemşireler üzerinde incelenmesi. Süleyman Demirel Üniversitesi İktisadi ve İdari Bilimler Fakültesi Dergisi, 2, 509-530.

Dorrian, J., Baulk, S. D. \& Dawson, D. (2011). Work hours, workload, sleep and fatigue in Australian Rail Industry employees. Applied Ergonomics, 42, 202- 209.

Dunham, R. B., Grube, J. A., \& Castaneda, M. B. (1994). Organizational commitment: the utility of an integrative definition. Journal of Applied Psychology, 79(3), 370-380.

Eren, E. (2006), Örgütsel Davranış ve Yönetim Psikolojisi, İstanbul, Beta Yayınları

Eslami, J. \& Gharakhani, D. (2012). Organizational commitment and job satisfaction, Journal of Science and Technology, 2(2).

Feather, N. T. \& Rauter, K. A. (2004). Organizational citizenship behaviours in relation to job status, job insecurity, organizational commitment and identification, job satisfaction and work values. Journal of Occupational and Organizational Psychology, 77, 81-94.

Folger, R. \& Konovsky, M.A. (1989). Effects of procedural and distributive justice on reactions to pay raise decisions, Academy of Management Journal, 32, 115-130. 


\section{F. Mansur - F. Seyhan 13/2 (2021) 1033-1049}

Fulford, M. D. (2005). That's not fair!: the test of a model of organizational justice, job satisfaction, and organizational commitment among hotel employees. Journal of Human Resources in HospitaliytETourism, number: 4 (1), 73-84.

Graham, J., Ramirez, A. J., Field, S. \& Richards, M.A. (2000). Job stress and satisfaction among clinical radiologists, Clinical Radiology, 55(3), 182-185.

Greenglass, E. R., Burke, R. J. \& Riksenbaum, L. (2001). Workload and burnout in nurses. Journal of Community $\mathcal{E}$ Applied Social Psychology, 11, 211-215.

Greenhaus, J. H., Parasuraman S., Granrose C.S., Rabinowitz, S. \& Beutell N.J. (1989) Sources of work- family conflict among two career couples. J. Vocational Behaviour, 34, 133-153.

Gutierrez, A.P., Candela,L.L. \& Carver L. (2012). The structural relationships between organizational commitment, global job satisfaction, developmental experiences, work values, organizational support, and person-organization fit among nursing faculty. Journal of Advanced Nursing. doi: 10.1111/j.13652648.2012.05990.x.

Gümüştekin, G. \& Öztemiz, A.B. (2004). Örgütsel stres yönetimi ve uçucu personel üzerinde bir uygulama, Erciyes Üniversitesi İktisadi ve İdari Bilimler Fakültesi Dergisi, 23 (Temmuz-Aralık), 61-85.

Gümüştekin, G. E. \& Öztemiz, B. (2005). Örgütlerde stresin verimlilik ve performansla etkileşimi. Çukurova Üniversitesi, Sosyal Bilimler Enstitüsü, 14(1), 271-288.

Hakanen, J.J., Schaufeli, W.B. \& Ahola, K. (2008). The job demands-resources model: a three-year cross-lagged study of burnout, depression, commitment, and work engagement, Work \& Stress, 22(3), 224-241.

Hammer, G. P., Scheidemann-Wesp, U., Samkange-Zeeb, F., Wicke, H., Neriishi, K. \& Blettner, M. (2013). Occupational exposure to low doses of 1onizing radiation and cataract development: a systematic literature review and perspectives on future studies. Radiation and Environmental Biophysics, 3: 303-319.

Hancock, P. \& Verwey, W. (1997). Fatigue, workload and adaptive driver systems. Accident Analysis and Prevention, 29, 495-506.

Hazriyanto \& Badaruddin, I. (2019). The factor analysis of organizational commitment, job satisfaction and performance among lecturers in batam, Journal of Technical Education and Training, 11 (1), 151-158.

Helvacı, M. (2011). Edirne'de iyonlaştırıcı radyasyon kaynakları ile çalışan să̆lık personelinin radyasyon güvenliği konusunda bilgi düzeyleri ve tutumları, Yüksek Lisans Tezi, Trakya Üniversitesi Sağlık Bilimleri Enstitüsü Halk Sağlığı Anabilim Dalı

Hoş, C. \& Oksay, A. (2015). Hemşirelerde örgütsel bağlllık ile iş tatmini ilişkisi, Süleyman Demirel Üniversitesi İktisadi ve İdari Bilimler Fakültesi Dergisi,.20(4), 1-24.

İnce, M. \& Gül, H. (2005): Yönetimde yeni bir paradigma: Örgütsel bağlllık, Çizgi Kitabevi.

Jermsittıparsert, K. \& Urairak, B. (2019). Exploring the nexus between emotional dissonance, leadership, organizational commitment, job satisfaction and intention to leave among medical professionals in Thailand, Utopía y Praxis Latinoamericana, 24(6) 378-386.

Jones, E., Chonko, L. B., Rangarajan, D. \& Roberts, J.A. (2007). The role of overload on job attitudes, turnover intentions, and salesperson performance. Journal of Business Research. 60. 663-671.

Judge, T. A. \& Watanabe, S. (1993). Another look at the job satisfaction-life satisfaction relationship. Journal of Applied Psychology, 78(6), 939-948.

Judge, T. A., Bono, J. E., Erez, A. \& Locke, E. A. (2005). Core self-evaluations and job and life satisfaction: The role of self-concordance and goal attainment. Journal of Applied Psychology, 90(2), 257-268.

Kanbur, E. (2018). Aşırı iş yükünün iş ve yaşam doyumu üzerindeki etkisi: işe bağlı gerginliğin aracı rolü, İş ve Insan Dergisi, Volume-Issue: 5 (2), 125-143

Karaca, B. (2001). İş tatmininin örgütsel bağlllık üzerindeki etkisi ve bir uygulama, Yüksek Lisans Tezi, Pamukkale Üniversitesi Sosyal Bilimler Enstitüsü. 
Karahan, A. (2009). Hekimlerin örgütsel bağlllık ve iş tatmini ilişkisinin incelenmesine yönelik bir araştırma: Afyon Kocatepe Üniversitesi Hastanesi örneği. Dumlupinar Üniversitesi Sosyal Bilimler Dergisi, 23, 421432.

Li, N., Zhang, L., Xiao, G., Chen, J., \& Lu Q.(2019). The relationship between workplace violence, job satisfaction and turnover intention in emergency nurses. Int Emerg Nurs. Jul;45, 50-55.

Locke, E. (1976). The nature and causes of job satisfaction, Dunnette, MD. (ed.), Handbook of Industrial and Organizational Psychology, Chicago (pp.1297-1349),

Lok, P. \& Crawford, J. (2004). The effect of organisational culture and leadership style on job satisfaction and organisational commitment: A cross-national comparison. Journal of Management Development, 23(4), 321-338.

Lum, L., Kervin, J., Clark, K., Reid, F. \& Sirola, W. (1998). Explaining nursing turnover intent: Job satisfaction, pay satisfaction, or organizational commitment? Journal of Organizational Behavior, 19(3), 305-320.

Maslach, C. \& Leiter, P.M. (1997). The Truth About Burnout, San Francisco: Jossey-Bass.

Mazloum, A., Kumashiro, M., Izumi, H. \& Higuchi, Y. (2008). Quantitative overload: A source of stress in dataentry vdt work induced by time pressure and work difficulty, Industrial Health, 46, 269-280.

Mayo, E. (1945). The Social problems of an industrial civilization. division of research, Graduate School of Business Administration, Harvard University.

Meyer, J. P., Stanley, D. J., Herscovitch, L., \& Topolnytsky L. (2001). Affective, continuance, and normative commitment to the organization: a meta-analysis of antecedents, correlates, and consequences. Journal of Vocational Behavior. 61, 20-52

Nasurdin, A.M. \& O'Driscoll, M.P. (2011). Work overload, parental demand, perceived organizational support, family support, and work-family conflict among New Zealand and Malaysian academics, New Zealand Journal of Psychology, 40(3), 38-48.

Nirel, N., Goldwag, R., Feigenberg, Z., Abadi, D. \& Halpern, P. (2008). Stress, work overload, burnout, and satisfaction among paramedics in Israel, Prehospital and Disaster Medicine, 23(6), 537-546.

Northcraft, G.B. \& Neale, M.A. (1990): Organizational Behavior, The Dryden Press.

Ocak, S., Gider, Ö., Gider, N. \& Top, M. (2017). Kişilik özelliklerinin örgütsel bağlllık ve örgütsel özdeşleşme üzerinde etkileri: bir kamu hastanesi örneği, İstanbul Üniversitesi İşletme Fakültesi İşletme Fakültesi İsletme İktisadı Enstitüsü Yönetim Dergisi, 82, 105-126.

Ramasodi, J.M.B. (2010). Factors influencing job satisfaction among healthcare professionals at south rand hospital. faculty of health systems. Management and Policy. University of Limpopo.

Rusu, R. (2013). Organizational commitment and job satisfaction, buletin Stiintific,1,(35).

Saygın, M., Yaşar, S., Çetinkaya, G., Kayan, M., Özgüner, M. F. \& Korucu, C. Ç. (2011). Radyoloji çalışanlarında depresyon ve anksiyete düzeyleri, Süleyman Demirel Üniversitesi Sağ̆lk Bilimleri Dergisi, 2(3): 139-144.

Sergeant, A. \& Frenkel, S. (2000). When Do Customer Contact Employees Satisfy Customers?, Journal of Service Research, number: 3 (1), 18-34.

Shantz, A., Arevshatian, L., Alfes, K. \& Bailey, C. (2016). The effect of hrm attributions on emotional exhaustion and the mediating roles of job involvement and work overload, Human Resource Management Journal, 26( 2), 172-191.

Sundaram, M.K. (2016). A study on relationships among job satisfaction, organizational commitment and turnover intention in kolors healthcare India Pvt. Ltd, Chennai, International Journal of Advanced Research in Management, 7(1), 58-71.

Sünter, T. A., Canbaz, S., Dabak, Ş. Öz, H. \& Pekşen, Y. (2006). Pratisyen hekimlerde tükenmişlik, işe bağlı gerginlik ve iş doyumu düzeyleri. Genel Tip Dergisi, 16(1), 9-14. 
Şaşkın, G. (2010). Radyolojide hasta ve çalışan güvenliği. Kurutkan, M.N. (ed.) Sağhlk Hizmetlerinde Çalı̧an Güvenliği, SAGE Yayıncılık, Ankara, 88-104

Tait, M., Padgett, M. Y. \& Baldwin, T. T. (1989). Job and life satisfaction: A reevaluation of the strength of the relationship and gender effects as a function of the date of the study. Journal of Applied Psychology, 74(3), 502-507.

Testa, M. R. (2001). Organizational commitment, job satisfaction, and effort in the service environment. The Journal of Psychology, 135(2), 226-236

Top, M. (2012). Hekim ve hemşirelerde örgütsel bağlllık, örgütsel güven ve iş doyumu profili, İstanbul Üniversitesi İşletme Fakültesi Dergisi, 41(2), 258-277.

Tutar, H. (2007). Erzurum'da devlet ve özel hastanelerde çalışan sağlık personelinin işlem adaleti, iş tatmini ve duygusal bağlllık durumlarının incelenmesi. Süleyman Demirel Üniversitesi İktisadi ve İdari Bilimler Fakültesi Dergisi, 12(3), 97-120.

Unni, K., Dag, H., Veenstra, M. \& Per, H. (2000). Predictors of job satisfaction among doctors, nurses and auxiliaries in Norwegian hospitals: Relevance for micro unit culture, Human Resources for Health. 4: 3.

Van, D. H. M. \& Geurts, S. (2001). Associations between ovetime and psychological health in high and level reward jobs. Work Stress, 15, 3-17.

Yüksel, İ. (2003). Hemşirelerin iş güçlüğü faktörlerinin belirlenmesi, iş doyumu ve örgütsel bağlllık üzerindeki etkisinin analizi. Öneri Dergisi, 5(20),131-139 